\title{
Genetic and nongenetic profiling of milk $\beta$-hydroxybutyrate and acetone and their associations with ketosis in Holstein cows
}

\author{
S.-L. Klein, (1) C. Scheper, (1) K. May, and S. König* (i) \\ Institute of Animal Breeding and Genetics, Justus Liebig University Giessen, 35390 Gießen, Germany
}

\begin{abstract}
Ketosis is a metabolic disorder of increasing importance in high-yielding dairy cows, but accurate population-wide binary health trait recording is difficult to implement. Against this background, proper Gaussian indicator traits, which can be routinely measured in milk, are needed. Consequently, we focused on the ketone bodies acetone and $\beta$-hydroxybutyrate (BHB), measured via Fourier-transform infrared spectroscopy (FTIR) in milk. In the present study, 62,568 Holstein cows from large-scale German co-operator herds were phenotyped for clinical ketosis (KET) according to a veterinarian diagnosis key. A sub-sample of 16,861 cows additionally had first test-day observations for FTIR acetone and BHB. Associations between FTIR acetone and BHB with KET and with test-day traits were studied phenotypically and quantitative genetically. Furthermore, we estimated SNP marker effects for acetone and BHB (application of genome-wide association studies) based on 40,828 SNP markers from 4,384 genotyped cows, and studied potential candidate genes influencing body fat mobilization. Generalized linear mixed models were applied to infer the influence of binary KET on Gaussian-distributed acetone and BHB (definition of an identity link function), and vice versa, such as the influence of acetone and $\mathrm{BHB}$ on KET (definition of a logit link function). Additionally, linear models were applied to study associations between BHB, acetone and test-day traits (milk yield, fat percentage, protein percentage, fat-to-protein ratio and somatic cell score) from the first test-day after calving. An increasing KET incidence was statistically significant associated with increasing FTIR acetone and BHB milk concentrations. Acetone and BHB concentrations were positively associated with fat percentage, fat-toprotein ratio and somatic cell score. Bivariate linear
\end{abstract}

Received February 10, 2020.

Accepted June 21, 2020.

*Corresponding author: sven.koenig@agrar.uni-giessen.de animal models were applied to estimate genetic (co) variance components for KET, acetone, BHB and testday traits within parities 1 to 3 , and considering all parities simultaneously in repeatability models. Pedigree-based heritabilities were quite small (i.e., in the range from 0.01 in parity 3 to 0.07 in parity 1 for acetone, and from 0.03-0.04 for BHB). Heritabilites from repeatability models were 0.05 for acetone, and 0.03 for BHB. Genetic correlations between acetone and BHB were moderate to large within parities and considering all parities simultaneously $(0.69-0.98)$. Genetic correlations between acetone and BHB with KET from different parities ranged from 0.71 to 0.99 . Genetic correlations between acetone across parities, and between BHB across parities, ranged from 0.55 to 0.66 . Genetic correlations between KET, acetone, and BHB with fatto-protein ratio and with fat percentage were large and positive, but negative with milk yield. In genome-wide association studies, we identified SNP on BTA 4, 10, 11, and 29 significantly influencing acetone, and on BTA 1 and 16 significantly influencing BHB. The identified potential candidate genes NRXN3, ACOXL, BCL2L11, HIBADH, KCNJ1, and PRG4 are involved in lipid and glucose metabolism pathways.

Key words: ketosis, acetone, $\beta$-hydroxybutyrate, genetic parameter, genome-wide association

\section{INTRODUCTION}

The period of negative energy balance after calving implies an imbalance between glucose supply and glucose requirement. In consequence, adipose tissue is mobilized and fatty acids are converted to ketone bodies, especially to acetone and BHB (David Baird, 1982). From a physiological perspective, ketones are fuel for the brain, the heart, and for muscle activities, but excessive amounts of ketone body levels cause the metabolic disorder ketosis (KET). In the context of farm economy, KET implies substantial economic losses due to effect on other diseases, reduced milk production in the ongoing lactation, and veterinary costs (Berg et al., 2002; Mostert et al., 2018). In most of 
the genetic and genomic studies, putative clinical cases of binary KET (producer records for either healthy or diseased cows) were considered because clinical cases are easier to detect than subclinical cases without any visible signs (Parker Gaddis et al., 2018). Nevertheless, additional consideration of subclinical KET cases in genetic and genomic analyses might contribute to improved prediction accuracies of genetic parameters, due to higher incidences. Incidences for clinical KET were lower than $2 \%$, but a large number of cows were diagnosed for subclinical KET (up to $47 \%$; Berge and Vertenten, 2014; Vanholder et al., 2015). Furthermore, subclinical KET was strongly associated with the occurrence of cost-intensive diseases and with decreased milk content (Suthar et al., 2013). However, for the detection of subclinical KET, detailed recording of proper traits, such as ketone body concentrations (acetone or BHB) in blood or in milk, is imperative (van Knegsel et al., 2010).

Phenotypic correlations between blood and milk ketone body concentrations were very strong for acetone (0.96), and moderate for BHB (0.66; Enjalbert et al., 2001). The phenotypic correlation between milk acetone and milk BHB was 0.68 (Enjalbert et al., 2001). Santschi et al. (2016) evaluated Fourier-transform infrared spectroscopy (FTIR) for the detection of ketone bodies in milk. Fourier-transform infrared spectroscopy is a cost-efficient, fast, and reliable alternative to blood ketone analysis and can be implemented in the routine process of monthly milk recording (Santschi et al., 2016). Grelet et al. (2016) used FTIR for the prediction of milk BHB and acetone concentrations. Prediction accuracies were quite large with 71 and $73 \%$, respectively.

With regard to quantitative genetic studies in Holstein cows, the genetic correlation between producerrecorded KET and first test-day milk FTIR measurements for BHB was 0.70 (Koeck et al., 2016). Lee et al. (2016) estimated heritabilities for FTIR milk BHB and acetone in parities 1 to 3 in Holstein cows. Earlylactation heritability estimates ranged between 0.04 and 0.10 for $\mathrm{BHB}$ and from 0.05 to 0.18 for acetone, depending on the lactation number. Häggman et al. (2019) also estimated low heritabilities of 0.07 for both milk BHB traits with linear models and of 0.12 with threshold models on the underlying liability scale. Weigel et al. (2017) used pedigree and SNP marker data and estimated a heritability of 0.07 for blood BHB. Heritability estimates for binary KET were small in the range from 0.01 to 0.08 (Belay et al., 2017; Parker Gaddis et al., 2018; Freebern et al., 2020).

In molecular genetic analyses, Kroezen et al. (2018) focused on the detection of potential candidate genes for producer-recorded KET and identified 6 genes influencing the lipid, ketogenic, and glucose metabolism. Kroezen et al. (2018) applied a case-control design for binary KET, but they also discussed the reduced statistical power of such a design for Gaussian-distributed BHB. Freebern et al. (2020) applied a GWAS and fine mapping to identify potential candidate genes related to disease traits in Holstein cattle. They identified one important segment (including the DGAT1 gene) on BTA 14 for KET. A first GWAS for FTIR BHB in milk was conducted by Nayeri et al. (2019). They identified significantly associated SNP markers on BTA 6, 14, and 20. The identified SNP on BTA 14 was located within the DGAT1 gene. The DGAT1 is a candidate gene influencing inflammatory response and lipid metabolism in dairy cattle (Mach et al., 2012).

So far, a few studies separately addressed physiological, quantitative genetics, and genomic associations for BHB, acetone, and KET. However, for a deeper understanding, it seems to be imperative to study physiological mechanisms on different scales (i.e., phenotypically, genetically, and genomically) simultaneously using the same cow data set. Consequently, the aim of this study was to infer statistic, quantitative genetic, and genomic associations between binary clinical KET and first test-day FTIR milk acetone and BHB concentrations in Holstein cows. Further aim was to study associations between acetone, BHB and KET with test-day traits from the very early-lactation period. Against this background, we applied generalized linear mixed models to study phenotypic trait relationships, we estimated genetic (co)variance components, we performed GWAS based on SNP marker data for acetone and BHB in milk, and we identified potential candidate genes influencing metabolic pathways.

\section{MATERIALS AND METHODS}

\section{Cow Traits}

The present study considered 65,777 Holstein cows from parities 1 to 3 , kept in 62 large-scale co-operator herds from the German federal states of MecklenburgWest Pomerania and Brandenburg. Calving ages ranged from 20 to 40 mo in parity 1, from 30 to 56 mo in parity 2 , and from 44 to $75 \mathrm{mo}$ in parity 3 . First test-day records after calving included milk yield, fat percentage, protein percentage, fat-to-protein ratio (FPR), SCS [transformed somatic cell count according to Ali and Shook (1980)], as well as acetone and BHB milk concentrations. The interval for the first official testday after calving comprised DIM 5 to 42 . Acetone and 
Table 1. Number of Holstein cows (no. of herds in parentheses) with acetone and BHB measurements and diagnoses for clinical ketosis

\begin{tabular}{|c|c|c|c|c|}
\hline \multirow[b]{2}{*}{ Trait } & \multicolumn{3}{|c|}{ Parity } & \multirow[b]{2}{*}{ No. of records ${ }^{1}$} \\
\hline & 1 & 2 & 3 & \\
\hline Acetone, BHB & $8,965(32)$ & $6,399(25)$ & $4,289(24)$ & $19,653(32)$ \\
\hline \multicolumn{5}{|l|}{ Ketosis } \\
\hline Healthy & $35,842(36)$ & $32,889(47)$ & $22,199(49)$ & $90,930(52)$ \\
\hline Diseased & $491(36)$ & $761(47)$ & $921(49)$ & $2,173(52)$ \\
\hline Ketosis, acetone, BHB & $5,874(18)$ & $5,604(19)$ & $3,791(20)$ & $15,269(22)$ \\
\hline
\end{tabular}

${ }^{1}$ No. of observations from all 3 parities.

BHB milk concentrations (in $\mathrm{m} M$ ) were determined using FTIR (Foss Analytics, Hillerød, Denmark). All testday traits followed a Gaussian distribution, based on residual analyses according to de Villemereuil (2018).

Veterinarians and herd manager phenotyped the cows for clinical KET based on a central disease diagnosis key (Stock et al., 2013). According to the recording guidelines, a KET score $=1$ for diseased cows was assigned for cows with at least one diagnosis for fever and increased content of ketone bodies in blood or urine (measured via handheld ketometers or urine test strips) in a 6-wk interval after calving. Hence, a score of 0 was assigned for healthy cows without any KET entry during this period. The number of Holstein cows and herds with acetone and BHB measurements and with clinical KET observations are shown in Table 1. The descriptive statistics for first test-day milk traits including acetone and BHB milk concentrations by parity are shown in Table 2.

\section{Genotypes}

A subset of 858 cows was genotyped with the Illumina BovineSNP50 v2 BeadChip (Illumina Inc., San Diego, CA), and 3,526 cows were genotyped with the EuroGenomics 10K chip (EuroGenomics, Amsterdam, the Netherlands). Genotyping was accomplished at the end of the project, with focus on first-parity cows, implying that most of the genotyped cows had no phenotypic records for later lactations. Low-density 10K genotypes were imputed by the project partner VIT (Vereinigte Informationssysteme Tierhaltung w.V, Verden, Germany) to the $50 \mathrm{~K}$ panel, applying the imputation design as described by Segelke et al. (2012). The SNP data set considered 45,613 SNP from 4,384 genotyped cows with phenotypic records for acetone and BHB. Quality control of the genotype data was performed using the software package PLINK (Purcell et al., 2007). The SNP with more than $1 \%$ missing

Table 2. Descriptive statistics for first test-day milk traits including acetone and BHB concentrations in parities 1,2 , and 3

\begin{tabular}{llcccc}
\hline Trait & Parity & Mean & SD & Minimum & Maximum \\
\hline Milk yield (kg) & 1 & 28.18 & 6.67 & 2.10 & 51.70 \\
& 2 & 38.40 & 8.13 & 3.00 & 62.40 \\
Fat (\%) & 3 & 40.41 & 8.74 & 2.30 & 68.00 \\
& 1 & 4.20 & 0.81 & 1.61 & 10.06 \\
Protein $(\%)$ & 2 & 4.34 & 0.82 & 1.83 & 10.34 \\
& 3 & 4.43 & 0.89 & 1.60 & 9.52 \\
Fat-to-protein ratio & 1 & 3.32 & 0.36 & 2.13 & 6.40 \\
& 2 & 3.34 & 0.39 & 2.23 & 5.02 \\
SCS & 3 & 3.31 & 0.39 & 2.30 & 6.23 \\
& 1 & 1.27 & 0.23 & 0.37 & 3.69 \\
Acetone $(\mathrm{m} M)$ & 2 & 1.30 & 0.23 & 0.50 & 3.26 \\
& 3 & 1.34 & 0.26 & 0.46 & 3.28 \\
BHB $(\mathrm{m} M)$ & 1 & 2.75 & 1.78 & -2.06 & 9.64 \\
& 2 & 2.17 & 1.89 & -3.64 & 9.64 \\
& 3 & 2.49 & 2.08 & -1.64 & 9.64 \\
& 1 & 0.05 & 0.10 & 0 & 2.05 \\
& 2 & 0.05 & 0.09 & 0 & 1.54 \\
& 3 & 0.06 & 0.12 & 0 & 2.89 \\
\end{tabular}


genotype data, with a minor allele frequency lower than $5 \%$, and deviation from Hardy-Weinberg equilibrium $\left(P<10^{-8}\right)$ were discarded. Thus, 40,828 SNP from the 4,384 cows were available for genomic studies.

\section{Statistical Models}

Statistical Associations Between Clinical Ketosis, Acetone, and BHB Concentrations. Generalized linear mixed models (GLMM) with an identity link function for Gaussian-distributed traits were applied to analyze the effect of clinical KET on the acetone and BHB concentrations from the first official test-day. In this regard, the Glimmix procedure as implemented in SAS (version 9.4, SAS Institute Inc., Cary, NC), was used. Associations were studied for parities 1 to 3 using a repeatability model. In this regard, we considered the cows with measurements for all 3 traits KET, acetone, and BHB (Table 1). The corresponding statistical Model 1 was defined as follows:

$$
\begin{gathered}
\mathrm{y}_{\mathrm{ijklmno}}=\varphi+\text { Herd }_{\mathrm{i}}+\text { CYear }_{\mathrm{j}}+\mathrm{DIM}_{\mathrm{k}}+\mathrm{CMon}_{\mathrm{l}} \\
+\mathrm{CAge}_{\mathrm{m}}+\mathrm{KET} \times \text { Parity }_{\mathrm{n}}+\text { Cow }_{\mathrm{o}}+\mathrm{e}_{\mathrm{ijklmno}},
\end{gathered}
$$

where $\mathrm{y}_{\mathrm{ijk} / m n o}=$ first test-day observation for acetone or BHB; $\varphi=$ overall mean; Herd $_{\mathrm{i}}=$ fixed herd effect; $\mathrm{CYear}_{\mathrm{j}}=$ fixed effect of calving year (2015-2017); DIM $_{\mathrm{k}}$ $=$ linear regression on DIM; $\mathrm{CMon}_{1}=$ fixed effect of calving month $(12 \mathrm{mo}) ; \mathrm{CAge}_{\mathrm{m}}=$ linear regression on calving age; KET $\times$ Parity $_{\mathrm{n}}=$ combined fixed effect of clinical KET (healthy or diseased) and parity (1, 2 , or 3$) ; \mathrm{Cow}_{\mathrm{o}}=$ random cow effect due to repeated measurements from different parities; $\mathrm{e}_{\mathrm{ijk} k \mathrm{mno}}=$ random residual effect.

Model 2 was applied to analyze the effect of first testday acetone and BHB concentrations on the disease probability for KET. In this regard, we used a GLMM with a logit link function for binary KET. Model 2 was

$$
\begin{aligned}
& \log \text { it }(\pi)=\log \left[\frac{\pi_{\text {rstuvwxy }}}{\left(1-\pi_{\text {rstuvwxy }}\right)}\right] \\
& =\varphi+\operatorname{Herd}_{\mathrm{r}}+\mathrm{CYear}_{\mathrm{s}}+\mathrm{DIM}_{\mathrm{t}}+\mathrm{CMon}_{\mathrm{u}}+\mathrm{CAge}_{\mathrm{v}} \\
& + \text { Parity }_{\mathrm{w}}+\mathrm{ACEcl}_{\mathrm{x}} \text { or BHBcl }_{\mathrm{x}}+\mathrm{Cow}_{\mathrm{v}},
\end{aligned}
$$

where $\pi_{\text {rstuvwxy }}=$ probability of a KET occurrence; Par$\mathrm{ity}_{\mathrm{w}}=$ fixed parity effect; $\mathrm{ACEcl}_{\mathrm{x}}$ or $\mathrm{BHBcl}_{\mathrm{x}}=$ fixed effect of acetone (2 classes: $<0.15 \mathrm{mM} ; \geq 0.15 \mathrm{mM}$ ) or BHB concentration [2 classes: $<0.10 \mathrm{~m} M ; \geq 0.10 \mathrm{~m} M$ as suggested by de Roos et al. (2007)]; and further effects as specified in Model 1.
Model 3 was defined to study the detailed influence of KET from different diagnosis dates during the earlylactation period on acetone and BHB. Model 3 was

$$
\begin{aligned}
\mathrm{y}_{\mathrm{ijklmnop}}=\varphi+ & \text { Herd }_{\mathrm{i}}+\text { CYear }_{\mathrm{j}}+\text { DIM }_{\mathrm{k}}+\text { CMon }_{1} \\
+ \text { CAge }_{\mathrm{m}} & + \text { Parity }_{\mathrm{n}}+\mathrm{KET} \times \text { Diffdat }_{\mathrm{o}} \\
& + \text { Cow }_{\mathrm{p}}+\mathrm{e}_{\mathrm{ijklmnop}}
\end{aligned}
$$

where $y_{\mathrm{ijklmnop}}=$ first test-day records for acetone or BHB concentration; KET $\times$ Diffdat $_{\mathrm{o}}=$ combined fixed effect of KET (healthy or diseased) $\times$ period between the first test date and the KET diagnosis date $(8$ classes considering the following periods: $37-21 \mathrm{~d}, 20-11 \mathrm{~d}$, 10-5 d, 4-1 d before the diagnosis date; $0-4 \mathrm{~d}, 5-10$ $\mathrm{d}, 11-20 \mathrm{~d}$, and $21-37 \mathrm{~d}$ after the diagnosis date); a dummy class for healthy cows; and further effects as specified in Models 1 and 2. Adjustment of $P$-values for multiple testing was done using the Dunnett statement in the Glimmix procedure (Dunnett, 1955).

Statistical Associations Between Test-Day Production Traits with Acetone and BHB Concentrations. The effects of acetone and BHB on the test-day traits milk yield, fat percentage, protein percentage, FPR and SCS were estimated using a GLMM with an identity link function. The statistical Model 4 was

$$
\begin{aligned}
\mathrm{y}_{\mathrm{ijklmnop}}=\varphi+ & \operatorname{Herd}_{\mathrm{i}}+\mathrm{CYear}_{\mathrm{j}}+\mathrm{DIM}_{\mathrm{k}}+\mathrm{CMon}_{1} \\
+\mathrm{CAge}_{\mathrm{m}} & + \text { Parity }_{\mathrm{n}}+\mathrm{ACE}_{\mathrm{o}}{\text { or } \mathrm{BHB}_{\mathrm{o}}} \\
& + \text { Cow }_{\mathrm{p}}+\mathrm{e}_{\mathrm{ijklmnop}},
\end{aligned}
$$

where $\mathrm{y}_{\mathrm{ijklmnop}}=$ observations for test-day traits, $\mathrm{ACE}_{\mathrm{o}}$ or $\mathrm{BHB}_{0}=$ linear regression on the acetone or $\mathrm{BHB}$ milk concentration (modeled via at-statements in SAS according to König et al., 2005), respectively, and further effects as specified in Model 1 and 2.

Estimation of Genetic Parameters. Pedigreebased (co)variance components and heritabilities for acetone and BHB were estimated using the AI-REML algorithm as implemented in the DMU software package (Madsen and Jensen, 2013). Heritabilities for acetone and BHB were estimated in single-trait animal models separately for parities 1, 2, and 3. Furthermore, we considered acetone and BHB from all 3 parities in single-trait repeatability models. Genetic statistical modeling considered the same fixed effects as specified in Model 1, but we excluded the combined KET $\times$ Parity effect. With regard to random effects, we included the random additive-genetic animal effect and the permanent environmental effect in repeatability models. In matrix notation, the genetic statistical Model 5 was 


$$
\mathbf{y}=\mathbf{X} \boldsymbol{\beta}+\mathbf{Z u}+\mathbf{W} \mathbf{p e}+\mathbf{e},
$$

where $\mathbf{y}$ was an observation vector for acetone or BHB; $\boldsymbol{\beta}$ was a vector of fixed effects including same effects as specified in Model 1 (without KET $\times$ Parity effect, and with parity effect in the repeatability model); $\mathbf{u}$ was a vector of additive-genetic effects, with $\mathbf{u} \sim N\left(0, \mathbf{A} \sigma_{u}^{2}\right)$, where $\mathbf{A}$ was the pedigree relationship matrix considering animals back to the birth year 1941, and $\sigma_{u}^{2}$ was the additive-genetic variance; pe was a vector of permanent environmental effects in the repeatability model, with pe $\sim N\left(0, \mathbf{I} \sigma_{p e}^{2}\right)$; e was a vector of random residual effects, with $\mathbf{e} \sim N\left(0, \mathbf{I} \sigma_{e}^{2}\right) ; \mathbf{I}$ being identity matrices for the number of cows and number of observations, respectively; and $\mathbf{X}, \mathbf{Z}$, and $\mathbf{W}$ were incidence matrices for $\boldsymbol{\beta}, \mathbf{u}$, and pe, respectively.

Genetic correlations among KET, acetone, BHB, and milk production traits, between acetone from different parities, and between BHB from different parities, were estimated via bivariate linear animal models (within parities) and via bivariate linear repeatability models (including records from different parities simultaneously). Hence, also binary KET was analyzed in bivariate linear-linear models. As proved by Vinson and Kliewer (1976), genetic correlations from bivariate linear and bivariate threshold models are expected to be the same. The model was defined as follows:

$$
\begin{aligned}
& {\left[\begin{array}{l}
\mathbf{y}_{1} \\
\mathbf{y}_{2}
\end{array}\right]=\left[\begin{array}{cc}
\mathbf{X}_{1} & 0 \\
0 & \mathbf{X}_{2}
\end{array}\right]\left[\begin{array}{l}
\boldsymbol{\beta}_{1} \\
\boldsymbol{\beta}_{2}
\end{array}\right]+\left[\begin{array}{cc}
\mathbf{Z}_{1} & 0 \\
0 & \mathbf{Z}_{2}
\end{array}\right]\left[\begin{array}{l}
\mathbf{u}_{1} \\
\mathbf{u}_{2}
\end{array}\right]} \\
& +\left[\begin{array}{cc}
\mathbf{W}_{1} & 0 \\
0 & \mathbf{W}_{2}
\end{array}\right]\left[\begin{array}{l}
\mathbf{p e}_{1} \\
\mathbf{p e}_{2}
\end{array}\right]+\left[\begin{array}{l}
\mathbf{e}_{1} \\
\mathbf{e}_{2}
\end{array}\right],
\end{aligned}
$$

where $\mathbf{y}_{1}$ and $\mathbf{y}_{2}$ were vectors of observations for the 2 traits; $\mathbf{X}_{1}$ and $\mathbf{X}_{2}$ were incidence matrices relating each observation to the fixed effects as specified for the single-trait Model 5 in $\boldsymbol{\beta}_{1}$ and $\boldsymbol{\beta}_{2} ; \mathbf{Z}_{1}$ and $\mathbf{Z}_{2}$ were incidence matrices relating the random additive-genetic effects of animals in $\mathbf{u}_{1}$ and $\mathbf{u}_{2}$ to each observation, $\mathbf{p e}_{1}$ and $\mathbf{p e}_{2}$ were the vectors for permanent environmental effects in repeatability models with corresponding incidences matrices $\mathbf{W}_{1}$ and $\mathbf{W}_{2}$; and $\mathbf{e}_{1}$ and $\mathbf{e}_{2}$ were the vectors for random residual effects for the 2 traits.

Genome-Wide Association Studies. A GWAS for acetone and BHB considering the 4,384 genotyped cows was performed using the software package GCTA (Yang et al., 2011). In this regard, we applied a linear mixed model and we specified the option of leaving one chromosome out (Yang et al., 2014). The corresponding model was

$$
\mathbf{y}=\mathbf{X} \boldsymbol{\beta}+\mathbf{Z u}+\mathbf{S s}+\mathbf{e}
$$

where $\mathbf{y}$ was the vector including records for acetone and BHB; $\boldsymbol{\beta}$ was a vector of fixed effects including the same effects specified in Model 5 (with parity); $\mathbf{u}$ was a vector of polygenic random effects of all SNP excluding those on the chromosome that carries a candidate SNP, with $\mathbf{u} \sim N\left(0, \mathbf{G} \sigma_{u}^{2}\right)$, with $\mathbf{G}$ denoting the genetic similarity matrix among individuals, and $\sigma_{u}^{2}$ the polygenic variance; $\mathbf{s}$ was the vector for fixed effects of the SNP tested for association coded as 0,1 , or 2 according to the respective allele dosage; e was a vector of random residual effects with $\mathbf{e} \sim N\left(0, \mathbf{I} \sigma_{e}^{2}\right)$; and $\mathbf{X}, \mathbf{Z}$, and $\mathbf{S}$ were incidence matrices for $\boldsymbol{\beta}, \mathbf{u}$, and $\mathbf{s}$, respectively. A small fraction of genotyped cows had phenotypic records in first lactations. Due to failed convergence when considering repeated measurements from these cows, we ignored the random permanent environmental effect in genomic analyses.

The effective number of independent SNP $\left(\mathrm{N}_{\mathrm{SNP}}=\right.$ 29,548 ) was calculated using the software Genetic type 1 Error Calculator (Li et al., 2012), to define the genomewide significance level according to Bonferroni ( $\mathrm{pBF}=$ $\left.0.05 / \mathrm{N}_{\mathrm{SNP}}=1.69 \mathrm{e}-06\right)$. In addition, a less conservative normative significance candidate threshold was used, considering pCD $=1 \mathrm{e}-04$ (Kurz et al., 2018). Genes located in a chromosomal window $250 \mathrm{~kb}$ upstream or downstream from the significantly associated SNP were detected using Ensembl, release 98, on the basis of the Bos taurus ARS1.2 genome assembly (Zerbino et al., 2018).

\section{RESULTS AND DISCUSSION}

\section{Statistical Associations Between Clinical Ketosis with Acetone and $B H B$}

A clinical KET diagnosis was associated with significantly higher first test-day acetone and BHB milk concentrations $(P<0.001$, Model 1$)$. The acetone and BHB concentrations for cows with a KET diagnosis was at least 2-fold higher compared with estimates for healthy cows. This was the case for all 3 lactations (Table 3 ). Nevertheless, the parity effect was highly significant $(P$ $<0.001$ ), showing a decrease of least squares means for acetone and BHB with increasing lactation number. Inferred associations reflect the physiological processes. In the stage of a negative energy balance and especially 
Table 3. Least squares means (corresponding SE in parentheses) of first test-day acetone and BHB concentrations in milk $(\mathrm{m} M)$ for cows with the absence (0) or the presence (1) of a ketosis diagnosis

\begin{tabular}{llrc}
\hline & & \multicolumn{2}{c}{ Ketosis diagnosis } \\
\cline { 3 - 4 } Trait & Parity & 0 & 1 \\
\hline Acetone & 1 & $0.08(0.00)^{\mathrm{a}}$ & $0.15(0.01)^{\mathrm{b}}$ \\
& 2 & $0.03(0.00)^{\mathrm{a}}$ & $0.10(0.01)^{\mathrm{b}}$ \\
BHB & 3 & $<0.00(0.00)^{\mathrm{a}}$ & $0.06(0.01)^{\mathrm{b}}$ \\
& 1 & $0.03(0.00)^{\mathrm{a}}$ & $0.06(0.01)^{\mathrm{b}}$ \\
& 2 & $0.01(0.00)^{\mathrm{a}}$ & $0.05(0.00)^{\mathrm{b}}$ \\
& 3 & $<0.00(0.00)^{\mathrm{a}}$ & $0.04(0.01)^{\mathrm{b}}$ \\
\hline
\end{tabular}

${ }^{\mathrm{a}, \mathrm{b}}$ Different superscripts indicate significant differences within parity $(P<0.001)$

for cows with a KET diagnosis, fatty acid oxidation from body fat depots and ongoing ketone production in the liver implies an accumulation of ketone bodies in blood and in milk (Andersson and Lundström, 1984). Results from Table 3 clearly indicate that FTIR milk ketones are useful indicators for the detection of clinical KET in early lactation. Similarly, using the same threshold for acetone $(\geq 0.15 \mathrm{mM})$ and BHB $(\geq 0.10 \mathrm{mM})$, de Roos et al. (2007) recommended FTIR acetone and BHB for the early detection of subclinical KET cases. Grelet et al. (2016) focused on cross-validations for KET detection, and could clearly distinguish between diseased and healthy cows based on FTIR spectrometry data.

Inversely, we detected a significant $(P<0.001)$ effect of acetone and BHB concentrations on KET incidences (results from Model 2). The probability for a clinical KET diagnosis was generally low, but significantly higher in cows with an acetone concentration above the threshold of $0.15 \mathrm{mM}$, and with a BHB concentration above the threshold of $0.10 \mathrm{mM}$, compared with the respective healthy cow group. Specifically, probabilities for a KET diagnosis were 4-fold higher for the cows allocated to the high acetone concentration $(\geq 0.15 \mathrm{mM})$ or to the high BHB concentration $(\geq 0.10 \mathrm{~m} M)$ group.
Due to the possible time lag between calving and first test-day date, a more frequent milk sampling in the critical period after calving could help to detect KET as early as possible. Acetone and BHB concentrations were significantly increased for KET diagnosed cows in the period from 37 to $20 \mathrm{~d}$ before the diagnosis date (Table 4), indicating that cows are suffering from elevated ketone body concentrations long time before clinical signs are obvious. Accordingly, van der Drift et al. (2012) detected the highest prevalence for hyperketonemia (defined as plasma BHB 1,200 $\mu \mathrm{mol} / \mathrm{L}$ ) in the very early lactation between 5 and 10 DIM. Results suggest utilization of earliest test-day milk samples to determine milk ketone bodies, and to consider results for acetone and BHB levels in preventive health management strategies. Addressing the period after a KET diagnosis, acetone substantially increased within the period of 20 to $37 \mathrm{~d}$, and BHB within the period of 11 to $20 \mathrm{~d}$ (Table 4). Klein et al. (2019) studied time lagged effects of KET diagnoses on KET indicator traits, and they confirmed the importance of the period comprising 20 to $30 \mathrm{~d}$ for metabolic disorders.

\section{Statistical Associations Between Acetone and BHB with Test-Day Production Traits}

Milk BHB and acetone significantly $(P \leq 0.001)$ affected milk yield (Figure 1), fat and protein percentage (Figure 2), FPR, and SCS (Figure 3). In agreement with the results from the present study, Chandler et al. (2018) and Santschi et al. (2016) identified a milk yield and protein percentage decline with increasing BHB and acetone concentrations. The decline in milk yield and protein percentage is due to impaired production processes requiring energy. Osorio et al. (2016) identified that especially protein synthesis in the mammary gland is a highly energy demanding process. Thus, due to energy deficiency in early lactation, protein synthesis

Table 4. Least squares means (corresponding SE in parentheses) of first test-day acetone and BHB milk concentrations ( $\mathrm{m} M$ ) for ketosis healthy cows and ketosis diseased cows (considered time periods: test-day dates before or after the ketosis diagnosis date)

\begin{tabular}{lcccccc}
\hline & & & Diseased cows & \\
\cline { 3 - 7 } Trait & Healthy cows & $\begin{array}{c}\text { Before or after } \\
\text { diagnosis }\end{array}$ & 37 to $21 \mathrm{~d}$ & 20 to $11 \mathrm{~d}$ & 10 to $5 \mathrm{~d}$ & 4 to $0 \mathrm{~d}^{1}$ \\
\hline Acetone & $0.03(0.00)$ & Before & $0.15(0.04)^{*}$ & $0.16(0.02)^{* * *}$ & $0.15(0.02)^{* * *}$ & $0.29(0.02)^{* * *}$ \\
& & After & $0.07(0.01)^{* *}$ & $0.08(0.01)^{* * *}$ & $0.07(0.01)^{*}$ & $0.18(0.02)^{* * *}$ \\
BHB & $0.01(0.00)$ & Before & $0.10(0.02)^{* *}$ & $0.06(0.01)^{* *}$ & $0.08(0.01)^{* * *}$ & $0.15(0.01)^{* * *}$ \\
& & After & $0.02(0.01)$ & $0.04(0.01)^{* * *}$ & $0.05(0.01)^{* * *}$ & $0.11(0.01)^{* * *}$ \\
\hline
\end{tabular}

${ }^{1} 4$ to $1 \mathrm{~d}$ before the ketosis diagnosis date, 0 to $4 \mathrm{~d}$ after the ketosis diagnosis date.

${ }^{*} P \leq 0.05 ;{ }^{* *} P \leq 0.01 ;{ }^{* *} P \leq 0.001$; adjusted $P$-values (Dunnett adjustment) for LSM differences between ketosis diseased and ketosis healthy cows. 


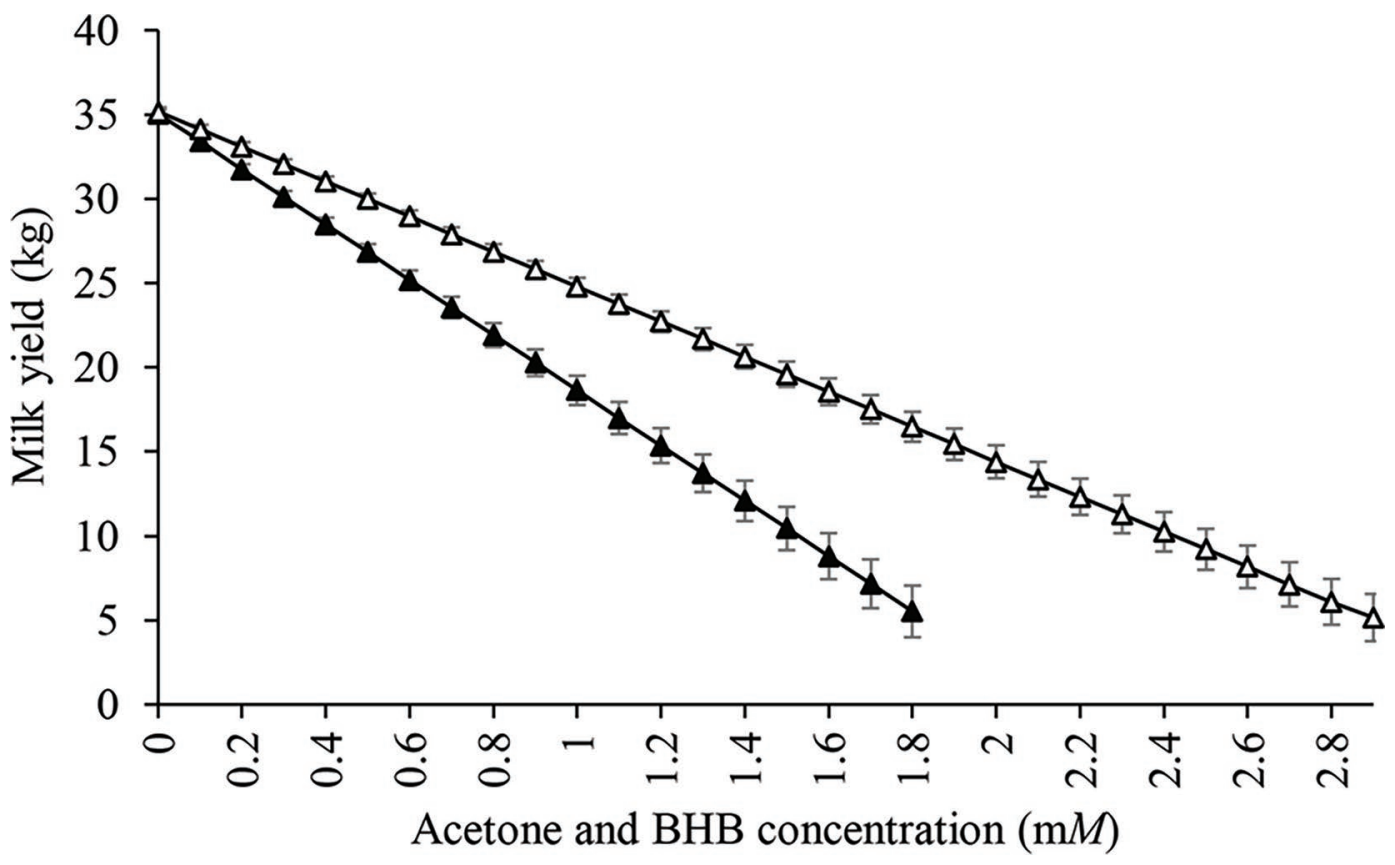

Figure 1. Least squares means with corresponding SE for first test-day milk yield in dependency of acetone $(\Delta$ indicates SE $=0.26-1.40)$ and BHB ( $\boldsymbol{\Lambda}$ indicates $\mathrm{SE}=0.03-1.53)$ milk concentrations.

might be restricted. As expected, fat percentage and FPR significantly increased with increasing ketone body concentrations in milk. The fat percentage and FPR increase is due to the strong body fat mobilization in the period of a negative energy balance, and the utilization of BHB for fatty acid synthesis in the mammary gland (Dodds et al., 1981). SCS increased with increasing BHB and acetone concentration. A possible explanation addresses immune responses in the mammary gland (i.e., an increasing production of somatic cells in response to excessive ketone body levels; Hillreiner et al., 2016). Santschi et al. (2016) created 3 classes for FTIR BHB concentrations $(<0.15 \mathrm{~m} M, 0.15-0.19$ $\mathrm{m} M$, and $\geq 0.20 \mathrm{~m} M)$. Holstein cows allocated to the extreme group with a BHB concentration $0.20 \mathrm{~m} M$ had substantial lower milk yield and protein percentage and higher fat percentage, FPR, and SCS compared with cows from the 2 other groups. Furthermore, we detected a significant association between acetone and BHB milk concentrations. The BHB concentration increased linear with increasing acetone concentration in milk (not shown).

\section{Heritabilities for Acetone and BHB and Genetic Correlations Among Acetone, BHB, Ketosis, and Test-Day Production Traits}

Heritabilities for milk ketone body concentrations from the first test-day are shown in Table 5. Heritabili- ties for acetone were $0.07(\mathrm{SE}=0.02)$ in first and second lactations, $0.01(\mathrm{SE}=0.01)$ in the third lactation, and $0.05(\mathrm{SE}=0.01)$ from the repeatability model. For $\mathrm{BHB}$, heritabilities were $0.04(\mathrm{SE}=0.01), 0.04(\mathrm{SE}=$ $0.02)$, and $0.03(\mathrm{SE}=0.02)$ in lactations 1,2 and 3 , respectively. The heritability for BHB from the repeatability model was $0.03(\mathrm{SE}=0.01)$. Due to the small permanent environmental variance component, repeatabilities for acetone and BHB were smaller than $10 \%$. Repeatabilities for same test-day production traits from different lactations were generally small, but quite large for different test-days within lactation (Gernand et al., 2007). In consequence, in most of the official national genetic evaluations, same test-day traits from different lactations are considered as different traits in multipletrait models.

The very small heritabilities for acetone and BHB in third-parity cows are due to a substantial increase of the residual variance component, especially for acetone. Nevertheless, the quite small heritabilities are in agreement with estimates by Weigel et al. (2017) and Häggman et al. (2019). Weigel et al. (2017) used blood BHB concentrations between d 5 and 18 postpartum, measured with a handheld blood ketone meter in 1,453 Holstein cows. They defined 3 different BHB traits: $\mathrm{BHB}_{\mathrm{MAX}}[$ maximum BHB blood concentration (mmol/L) from twice weekly sampling between 5-18 d postpartum], $\mathrm{BHB}_{\mathrm{SORT}}$ (square root of $\mathrm{BHB}_{\mathrm{MAX}}$ ) and $\mathrm{BHB}_{\mathrm{BIN}}$ (binary scale, 1 if $\mathrm{BHB}_{\mathrm{MAX}} \geq 1.2 \mathrm{mmol} / \mathrm{L} ; 0$ if 


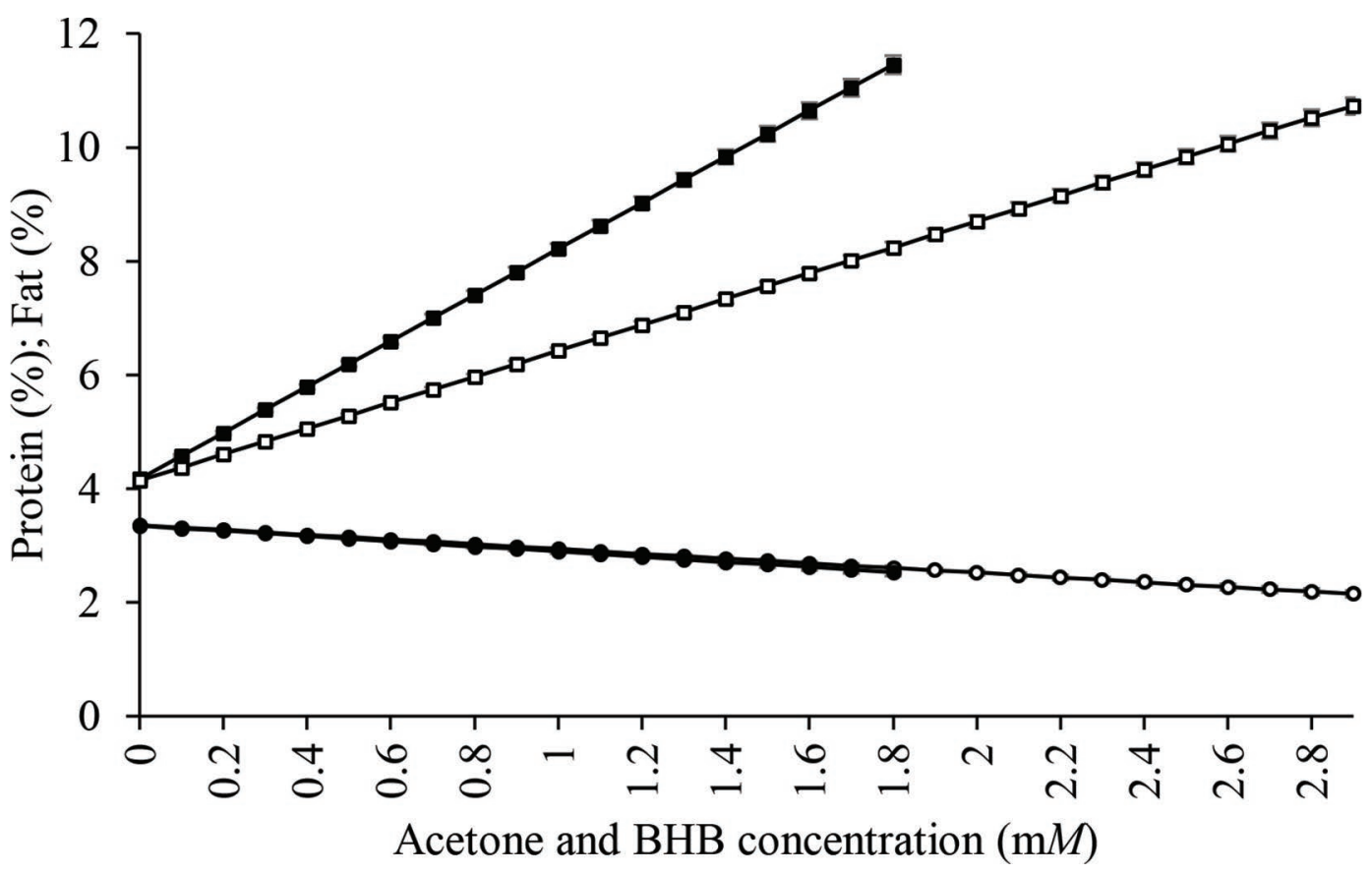

Figure 2. Least squares means with corresponding SE for first test-day protein percentage $(\bigcirc$ indicates $\mathrm{SE}=0.01-0.06$; $\bullet$ indicates $\mathrm{SE}=$ $0.01-0.07)$ and fat percentage ( $\square$ indicates $\mathrm{SE}=0.03-0.05$; $\boldsymbol{\square}$ indicates $\mathrm{SE}=0.03-0.06)$ in dependency of acetone (white symbols) and BHB (black symbols) milk concentrations.

$\left.\mathrm{BHB}_{\mathrm{MAX}}<1.2 \mathrm{mmol} / \mathrm{L}\right)$. Heritabilities for the 3 traits ranged between $0.06(\mathrm{SE}=0.04)$ and $0.07(\mathrm{SE}=0.05)$. Häggman et al. (2019) grouped BHB measurements into 3 classes and estimated heritabilities with linear animal models. Heritabilities for BHB in the different classes ranged from 0.07 to 0.09. Lee et al. (2016) focused on FTIR milk ketones from different lactation stages after calving (30 DIM, 150 DIM, and 250 DIM) in parities 1 to 3 . According to our results, heritability estimates for acetone and BHB slightly decreased with increasing parity. Satoła and Ptak (2019) detected larger permanent environmental and residual variances in later lactations than in first-parity cows, indicating stronger nongenetic influence on trait variability with aging. The quite large heritability estimates up to 0.36 for acetone and 0.14 for BHB in the studies by Lee et al. (2016) and Ranaraja et al. (2018) are possibly due to pronounced phenotypic trait variations and a smaller residual component in later lactation stages.

Genetic correlations between acetone and BHB with KET were in the range from 0.71 to 0.99 for the different parities, with moderate to large SE (0.07-0.27) (Table 5). The large genetic correlations per parity between clinical KET and ketone concentrations suggest consideration of milk acetone and milk BHB in health selection indices to improve resistance against metabolic disorders (König and May, 2018). Genetic correla- tions between acetone and BHB with KET from the repeatability model were lower and ranged from 0.22 to 0.37 ( $\mathrm{SE}=0.12-0.14$; Table 5). Koeck et al. (2016) defined different traits for FTIR milk BHB based on means, averages and SD from repeated measurement data. Genetic correlations between the different BHB definitions with producer-recorded KET ranged from 0.64 to 0.82. In contrast, Belay et al. (2017) estimated low to moderate genetic correlations between KET and BHB traits in the range from 0.18 and 0.47 , whereas correlations decreased with DIM. In the present study, genetic correlations between acetone measurements from different parities and between BHB measurements from different parties ranged from 0.55 to 0.66 . The moderate to large correlations suggest early selection on FTIR profiles in first-parity cows. Nevertheless, SE of genetic correlation estimates were quite large $(0.18-0.30)$. Genetic correlations between acetone and BHB for the different parities ranged from 0.69 to 0.98 $(\mathrm{SE}=0.13-0.33)$.

Genetic correlations between acetone, BHB, and KET with test-day traits (Table 6) reflect the phenotypic associations. First test-day milk yield and protein percentage were negatively correlated with acetone, $\mathrm{BHB}$, and KET, whereas correlations between fat percentage, FPR, and SCS with acetone, BHB, and KET were positive (Table 6). This was the case for both 
Table 5. Pedigree-based heritabilities $\left(\mathrm{h}^{2} ; \mathrm{SE}\right.$ in parentheses), additive-genetic $\left(\times 10^{-3}\right)$, permanent environmental $\left(\times 10^{-3}\right)$, and residual $\left(\times 10^{-3}\right)$ variances for acetone and BHB milk concentrations, and their genetic correlations $\left(\mathrm{r}_{\mathrm{g}}\right.$ ) with clinical ketosis (KET; SE in parentheses)

\begin{tabular}{|c|c|c|c|c|c|c|}
\hline \multirow[b]{2}{*}{ Trait } & \multirow[b]{2}{*}{ Parity } & \multirow[b]{2}{*}{$\mathrm{h}^{2}$} & \multicolumn{3}{|c|}{ Variance } & \multirow[b]{2}{*}{$\mathrm{r}_{\mathrm{g}}$ with KET } \\
\hline & & & $\begin{array}{l}\text { Additive- } \\
\text { genetic }\end{array}$ & $\begin{array}{c}\text { Permanent } \\
\text { environmental }\end{array}$ & Residual & \\
\hline \multirow[t]{4}{*}{ Acetone } & 1 & $0.07(0.02)$ & 0.71 & & 8.81 & $0.82(0.17)$ \\
\hline & 2 & $0.07(0.02)$ & 0.45 & & 6.07 & $0.96(0.07)$ \\
\hline & 3 & $0.01(0.01)$ & 0.20 & & 13.98 & $0.99(0.27)$ \\
\hline & $\mathrm{All}^{1}$ & $0.05(0.01)$ & 0.40 & 0.36 & 8.80 & $0.22(0.12)$ \\
\hline \multirow[t]{4}{*}{ BHB } & 1 & $0.04(0.01)$ & 0.09 & & 2.40 & $0.71(0.21)$ \\
\hline & 2 & $0.04(0.02)$ & 0.13 & & 3.00 & $0.99(0.10)$ \\
\hline & 3 & $0.03(0.02)$ & 0.13 & & 4.23 & $0.71(0.15)$ \\
\hline & All & $0.03(0.01)$ & 0.09 & $<0.00$ & 3.04 & $0.37(0.14)$ \\
\hline
\end{tabular}

${ }^{1} \mathrm{All}=$ consideration of records from all 3 parities simultaneously in a repeatability model.

modeling strategies (i.e., the analyses within parities or repeated measurement applications).

The negative genetic correlations between acetone and BHB with milk yield and protein percentage are in line with results from previous studies (Koeck et al., 2013; Lee et al., 2016; Belay et al., 2017). The positive genetic correlations between fat percentage and FPR with milk ketone bodies support results by Lee et al. (2016), Ranaraja et al. (2018) and Mehtiö et al. (2020). The positive genetic correlations between SCS with milk ketone body concentrations or with KET indicate that KET and mastitis are genetically related in the early-lactation period (Heringstad et al., 2005).
Again, correlations from the repeatability model were smaller compared with estimates within lactation. The generally lower genetic correlations from the repeatability model lead us to conclude that consideration of repeated measurements from different lactations with very low repeatabilities might bias genetic parameter estimates.

\section{Genome-Wide Association Studies for Acetone and BHB}

We identified 9 SNP significantly associated with acetone and BHB FTIR concentrations in milk accord-

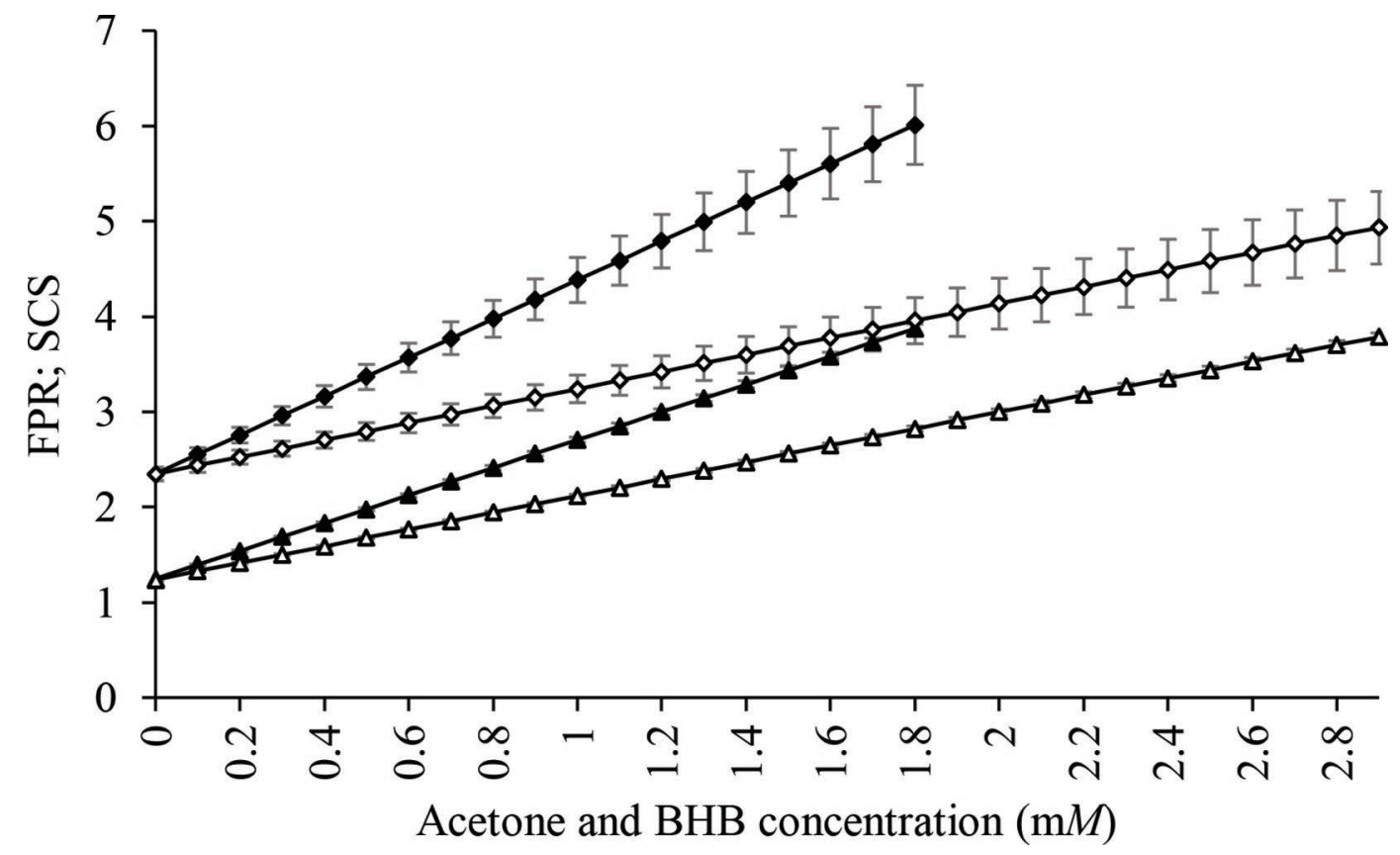

Figure 3. Least squares means with corresponding SE for first test-day fat-to-protein ratio (FPR; $\Delta$ indicates $\mathrm{SE}=0.01-0.04 ; \boldsymbol{\Delta}$ indicates $\mathrm{SE}=0.01-0.05)$ and somatic cell score (SCS; $\diamond$ indicates $\mathrm{SE}=0.07-0.28 ; \bullet$ indicates $\mathrm{SE}=0.07-0.32)$ in dependency of acetone (white symbols) and BHB (black symbols) milk concentrations. 
Table 6. Genetic correlations between clinical ketosis (KET), acetone, and BHB milk concentrations with first test-day traits from parities 1, 2, and 3 (corresponding $\mathrm{SE}$ in parentheses)

\begin{tabular}{|c|c|c|c|c|}
\hline Trait & Parity & Acetone & $\mathrm{BHB}$ & KET \\
\hline \multirow[t]{4}{*}{ Milk yield (kg) } & 1 & $-0.51(0.06)$ & $-0.57(0.07)$ & $-0.52(0.08)$ \\
\hline & 2 & $-0.73(0.05)$ & $-0.67(0.08)$ & $-0.74(0.04)$ \\
\hline & 3 & $-0.89(0.06)$ & $-0.84(0.08)$ & $-0.82(0.03)$ \\
\hline & $\mathrm{All}^{1}$ & $-0.11(0.10)$ & $-0.18(0.12)$ & $-0.08(0.06)$ \\
\hline \multirow[t]{4}{*}{ Fat $(\%)$} & 1 & $0.78(0.03)$ & $0.86(0.03)$ & $0.68(0.08)$ \\
\hline & 2 & $0.85(0.02)$ & $0.85(0.03)$ & $0.70(0.06)$ \\
\hline & 3 & $0.91(0.03)$ & $0.91(0.02)$ & $0.74(0.05)$ \\
\hline & All & $0.42(0.08)$ & $0.65(0.08)$ & $0.15(0.06)$ \\
\hline \multirow[t]{4}{*}{ Protein (\%) } & 1 & $-0.67(0.06)$ & $-0.48(0.10)$ & $-0.67(0.09)$ \\
\hline & 2 & $-0.74(0.06)$ & $-0.60(0.10)$ & $-0.59(0.10)$ \\
\hline & 3 & $-0.78(0.10)$ & $-0.63(0.13)$ & $-0.53(0.07)$ \\
\hline & All & $-0.54(0.08)$ & $-0.32(0.10)$ & $-0.37(0.04)$ \\
\hline \multirow[t]{4}{*}{ Fat-to-protein ratio } & 1 & $0.88(0.02)$ & $0.91(0.02)$ & $0.86(0.06)$ \\
\hline & 2 & $0.92(0.02)$ & $0.92(0.02)$ & $0.84(0.04)$ \\
\hline & 3 & $0.92(0.02)$ & $0.92(0.02)$ & $0.83(0.04)$ \\
\hline & All & $0.73(0.06)$ & $0.82(0.06)$ & $0.39(0.05)$ \\
\hline \multirow[t]{4}{*}{ SCS } & 1 & $0.38(0.10)$ & $0.61(0.11)$ & $0.42(0.14)$ \\
\hline & 2 & $0.33(0.14)$ & $0.46(0.17)$ & $0.39(0.13)$ \\
\hline & 3 & $0.99(0.22)$ & $0.67(0.21)$ & $0.04(0.11)$ \\
\hline & All & $0.13(0.11)$ & $0.24(0.13)$ & $0.12(0.07)$ \\
\hline
\end{tabular}

${ }^{1}$ All $=$ consideration of records from all 3 parities simultaneously in a repeatability model.

ing to the candidate threshold (Supplemental Table S1, https://doi.org/10.3168/jds.2019-18339). The $-\log _{10}$ $P$-values of the tested SNP are shown in Figure 4 (for acetone) and in Figure 5 (for BHB) as Manhattan plots. In total, 28 positional candidate genes in the interval of $250 \mathrm{~kb}$ surrounding the significant SNP (Supplemental Table S2, https://doi.org/10.3168/jds .2019-18339) were retrieved from the Ensembl database (Zerbino et al., 2018). In the following, we focused on inferring potential candidate genes possibly related to acetone or BHB due to their functional or physiological background.
Acetone. Significantly associated SNP were identified on BTA 4, 10, 11, and 29 (Figure 4, Supplemental Table S1). The SNP rs29021343 on BTA 10 $(90,924,914 \mathrm{bp})$ with the highest $-\log _{10} P$-value is located in the gene neurexin 3 (NRXN3, 90,495,25891,099,930 bp). Zhang et al. (2017) applied a genetic pleiotropic conditional false discovery rate approach and discovered loci associated with obesity and type-2 diabetes. In their study, an SNP variant associated with obesity and diabetes in humans was located in the NRXN3 gene. Because diabetes and obesity are strongly related to KET and energy deficiency in

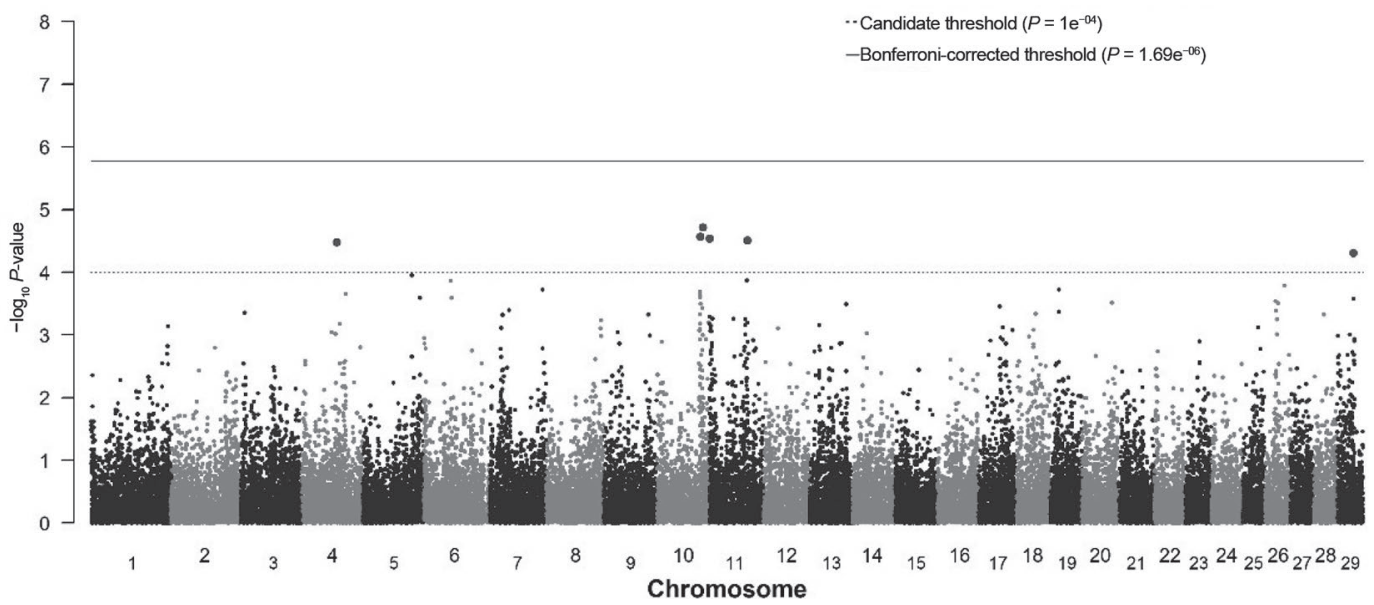

Figure 4. Manhattan plot for $-\log _{10} P$-values of SNP effects for first test-day milk acetone concentration $(\mathrm{m} M)$ in Holstein cows. 


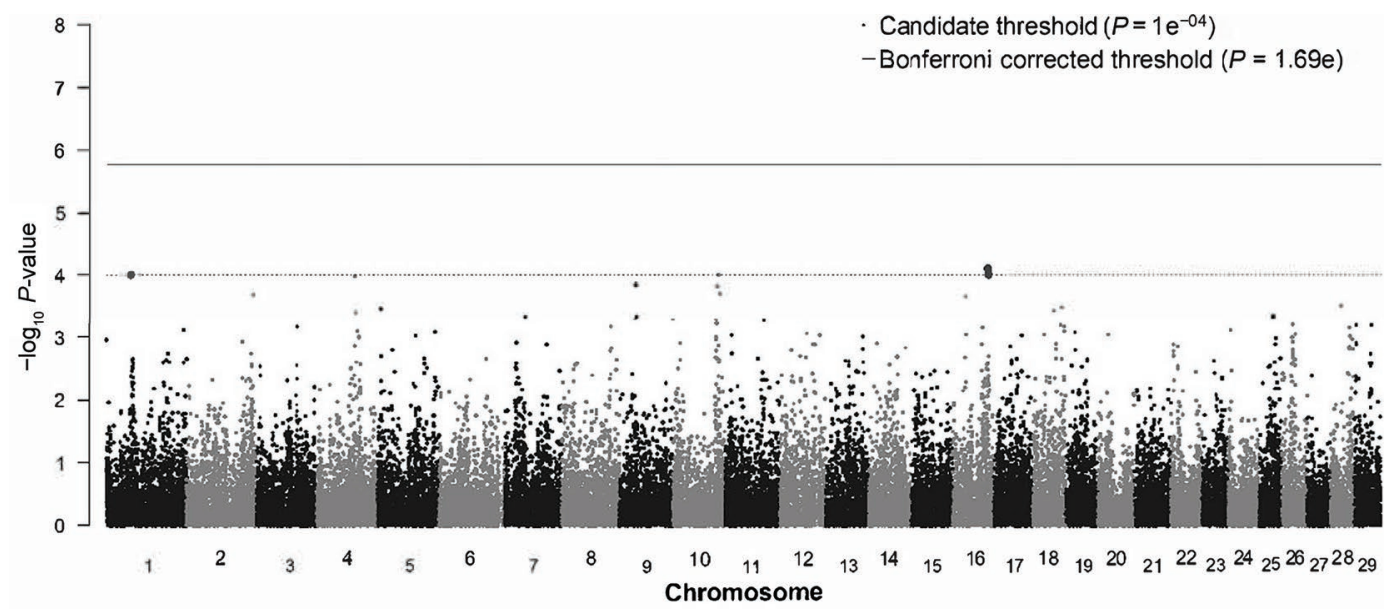

Figure 5. Manhattan plot for $-\log _{10} P$-values of SNP effects for first test-day milk BHB concentration $(\mathrm{m} M)$ in Holstein cows.

early lactation (Hayirli, 2006), NRXN3 is a potential candidate gene for metabolic disorders. As described by Hayirli (2006), cows with clinical KET have a low responsiveness to insulin due to ketoacidosis. Ketosis symptoms and associated physiological mechanisms in cows show similarities to diabetes in humans. In this regard, Lucy (2004) identified similar characteristics when comparing diabetic states in humans and low insulin states postpartum in cows (e.g., low insulin levels or insulin resistance). Insulin inhibits lipolysis, regulates ketone body output from the liver, and enhances ketone utilization in peripheral tissues (Fukao et al., 2004). In causality, low insulin levels initiate adipocyte lipolysis and liver accumulation with fatty acids.

The SNP rs110395452 on BTA $11(1,283,185 \mathrm{bp})$ is localized in the gene acyl-CoA oxidase like $(A C O X L$, $1,237,943-1,576,166 \mathrm{bp}$ ), and also located in close chromosomal distance to the gene BCL2 like 11 (BCL2L11, 1,187,496-1,233,256 bp). According to Fang et al. (2017) and Hasstedt et al. (2013), ACOXL and BCL2L11 are associated with diabetes in humans. Genome-wide expression profiling (Fang et al., 2017) showed significant upregulation of BCL2L11 in type-1 diabetes mellitus samples compared with healthy controls. These results suggest an involvement of BCL2L11 in cell death of islet $\beta$-cells in the pathogenesis of diabetes. As reported by Hasstedt et al. (2013), the lipid metabolism gene ACOXL contributed to diabetes as well. Also, Hayirli (2006) clearly described the physiological interactions between KET and insulin regulations and stretched the insulin resistance phenomenon in postpartum dairy cows. The second significantly associated SNP rs109102963 on BTA $11(75,410,689 \mathrm{bp})$ is located in the gene kelch like family member 29 (KLHL29,
$75,240,502-75,572,709 \mathrm{bp})$ and in close chromosomal distance to the gene ATPase family AAA domain containing 2B (ATAD2B, 75,091,973-75,213,880 bp). Both genes KLHL29 and ATAD2B are putative candidate genes for milk protein composition traits in Chinese Holstein cows (Zhou et al., 2019).

The gene 3-hydroxyisobutyrate dehydrogenase (HIBADH, 68,473,794-68,614,954 bp) in the defined interval surrounding SNP rs109374730 (68,808,125 bp) on BTA 4 is associated with KET related fatty liver disease and negative energy balance in early-lactation cows (McCarthy et al., 2010; Sejersen et al., 2012). McCarthy et al. (2010) indicated that HIBADH was downregulated in cows with severe negative energy balance. Sejersen et al. (2012) described significant influence of fatty liver disease on $H I B A D H$ expression. Cows with high accumulation of liver triglycerides indicating fatty liver disease showed a significant downregulation of $H I B A D H$ in the liver. Additionally, $H I B A D H$ was correlated with plasma BHB and bilirubin. Apart from that, downregulated HIBADH in humans' adipose tissue was associated with insulin resistance (Wiklund et al., 2016). Furthermore, the gene $H I B A D H$ regulates fatty acid transport and enhances lipid accumulation and was increased in mice and human with diabetes (Jang et al., 2016).

On BTA 29, the gene potassium voltage-gated channel subfamily J member 1 (KCNJ1, 32,214,439-32,244,810 $\mathrm{bp}$ ) is located in close chromosomal distance to the significantly associated SNP rs41651011 (32,373,604 bp). Karnes et al. (2013) reported that KCNJ1 is associated with abnormal blood sugar levels and diabetes. Alterations of blood sugar levels and a state of insulin resistance are characteristics for the period around calving, because insulin depended transfer of glucose 
into the mammary gland is prioritized (De Koster and Opsomer, 2013).

$B \boldsymbol{B}$. Three potential candidate SNP were identified for the FTIR BHB concentration (Figure 5, Supplemental Table S1, https://doi.org/10.3168/jds .2019-18339). The marker rs109480845 (67,532,667 bp) with the strongest association is located on BTA 16, in close chromosomal distance to the gene proteoglycan 4 (PRG4, 67,381,599-67,398,481 bp). Geyer et al. (2016) identified effect of PRG4 on the glucose and lipid metabolism. Nahon et al. (2019) described the influence of $P R G_{4}$ on glucose intolerance and fatty liver disease in mice. For the SNP rs109224751 $(68,984,620 \mathrm{bp})$ on BTA 16 and the SNP rs111002696 (47,765,383 bp) on BTA 1 , no potential candidate genes explaining metabolic diseases, were identified. Genome-wide associations based on producer-recorded KET in Holstein cows (Huang et al., 2019) and US Jerseys (Parker Gaddis et al., 2018) detected significant SNP markers on BTA 10 and 11, with annotated potential candidate genes involved in insulin regulation and lipid metabolism. These chromosomal segments were in a distance of approximately $1 \mathrm{Mb}$ to our significantly associated SNP on BTA 10 and 11. Applying a single SNP regression mixed linear model and enrichment analysis, Nayeri et al. (2019) detected significantly associated SNP on BTA 6,14 , and 20. Ongoing pathway analyses inferred associations with the lipid metabolism and immune functions. In the present study, we did not find signals on BTA 14 indicating the DGAT1 gene. Accordingly, GWAS in a previous study (Klein et al., 2019) with different statistical approaches suggested significant SNP within DGAT1 for FPR, but not for KET. The authors concluded that these SNP from the DGAT1 segment influence milk fat synthesis, but not contribute to the mobilization of body fat depots in the stage of negative energy balance. Tetens et al. (2012) mentioned the narrow correlations between FPR and energy balance indicators, but they did not identify quantitative trait loci affecting both traits simultaneously. Also in their study, DGAT1 was only relevant for FPR.

The significantly associated SNP and annotated potential candidate genes from different chromosomes suggest a strong polygenic effect on milk acetone and BHB. The number of SNP surpassing the candidate threshold ( $\mathrm{pCD}=1 \mathrm{e}-04)$ was limited $(9 \mathrm{SNP})$ and $\log _{10} P$-values of significantly associated SNP were quite low. As stated by Goddard et al. (2016), complex traits are more complex than presumed and influenced by thousands of SNP with very small effects. This is also true for the KET indicators acetone and BHB. All SNP effects were too small to be significant when considering the strict Bonferroni corrected $P$-value. McCarthy et al. (2008) proposed to enlarge the sample size to improve the statistical power in GWAS for complex traits with low incidences. Furthermore, cow genotyping with a denser SNP chip (as done by Freebern et al., 2020) might influence significance tests in GWAS.

\section{CONCLUSIONS}

The strong phenotypic associations between first test-day FTIR acetone and FTIR BHB with KET suggest routinely determination and utilization of ketone bodies in milk, to improve the dairy cow health management. Furthermore, we identified pronounced favorable genetic correlations among KET, FTIR acetone, FTIR BHB, and FPR within parities 1 to 3, and moderate genetic correlations from the repeatability model. Hence, from a breeding perspective, results suggest consideration of milk ketone bodies in selection indices for metabolic disorders. The strong genetic correlations between FTIR acetone and BHB from first lactation with the respective traits in later lactations indicate the usefulness of early selection in first-parity cows. Pedigree-based heritabilities for acetone and BHB were quite small. Nevertheless, we identified a small number of significantly associated SNP markers on 6 different chromosomes. The identified potential candidate genes in close chromosomal distance (i.e., NRXN3, ACOXL, BCL2L11, HIBADH, KCNJ1 and PRG4) are involved in human diabetes, lipid, and glucose metabolism pathways.

\section{ACKNOWLEDGMENTS}

The authors gratefully acknowledge funding from the German Federal Ministry of Education and Research (BMBF, 53175 Bonn, Germany) and from the Forderverein Bioökonomieforschung e.V. (FBF, 53113 Bonn, Germany)/German Holstein Association (DHV, today part of German Livestock Association, 53113 Bonn, Germany) for the collaborative project KMUinnovativ-10: Kuh-L - cow calibration groups for the implementation of selection strategies based on highdensity genotyping in dairy cattle. The authors have not stated any conflicts of interest.

\section{REFERENCES}

Ali, A. K. A., and G. E. Shook. 1980. An optimum transformation for somatic cell concentration in milk. J. Dairy Sci. 63:487-490. https: //doi.org/10.3168/jds.S0022-0302(80)82959-6.

Andersson, L., and K. Lundström. 1984. Effect of energy balance on plasma glucose and ketone bodies in blood and milk and influence of hyperketonaemia on milk production of postparturient dairy cows. Zentralbl. Veterinärmed. A 31:539-547. https://doi.org/10 .1111/j.1439-0442.1984.tb01312.x. 
Baird, G. D. 1982. Primary ketosis in the high-producing dairy cow: Clinical and subclinical disorders, treatment, prevention, and outlook. J. Dairy Sci. 65:1-10. https://doi.org/10.3168/jds.S0022 -0302(82)82146-2.

Belay, T. K., M. Svendsen, Z. M. Kowalski, and T. Ådnøy. 2017. Genetic parameters of blood $\beta$-hydroxybutyrate predicted from milk infrared spectra and clinical ketosis, and their associations with milk production traits in Norwegian Red cows. J. Dairy Sci. 100:6298-6311. https://doi.org/10.3168/jds.2016-12458.

Berg, J. M., J. L. Tymoczko, and L. Stryer. 2002. Each organ has a unique metabolic profile. Biochemistry. 5th ed. W.H. Freeman, New York.

Berge, A. C., and G. Vertenten. 2014. A field study to determine the prevalence, dairy herd management systems, and fresh cow clinical conditions associated with ketosis in western European dairy herds. J. Dairy Sci. 97:2145-2154. https://doi.org/10.3168/jds .2013-7163

Chandler, T. L., R. S. Pralle, J. R. R. Dórea, S. E. Poock, G. R. Oetzel, R. H. Fourdraine, and H. M. White. 2018. Predicting hyperketonemia by logistic and linear regression using test-day milk and performance variables in early-lactation Holstein and Jersey cows. J. Dairy Sci. 101:2476-2491. https://doi.org/10.3168/jds 2017-13209

de Villemereuil, P. 2018. Quantitative genetic methods depending on the nature of the phenotypic trait. Ann. N. Y. Acad. Sci. 1422:2947. https://doi.org/10.1111/nyas.13571.

De Koster, J. D., and G. Opsomer. 2013. Insulin resistance in dairy cows. Vet. Clin. North Am. Food Anim. Pract. 29:299-322. https: //doi.org/10.1016/j.cvfa.2013.04.002.

de Roos, A. P., H. J. van den Bijgaart, J. Hørlyk, and G. de Jong. 2007. Screening for subclinical ketosis in dairy cattle by Fourier transform infrared spectrometry. J. Dairy Sci. 90:1761-1766. https: //doi.org/10.3168/jds.2006-203.

Dodds, P. F., M. G. Guzman, S. C. Chalberg, G. J. Anderson, and S. Kumar. 1981. Acetoacetyl-CoA reductase activity of lactating bovine mammary fatty acid synthase. J. Biol. Chem. 256:6282-6290.

Dunnett, C. W. 1955. A multiple comparison procedure for comparing several treatments with a control. J. Am. Stat. Assoc. 50:10961121. https://doi.org/10.1080/01621459.1955.10501294.

Enjalbert, F., M. C. Nicot, C. Bayourthe, and R. Moncoulon. 2001. Ketone bodies in milk and blood of dairy cows: Relationship between concentrations and utilization for detection of subclinical ketosis. J. Dairy Sci. 84:583-589. https://doi.org/10.3168/jds.S0022 $-0302(01) 74511-0$.

Fang, C., Y. Huang, Y. Pei, H.-H. Zhang, X. Chen, H. Guo, S. Li, X. Ji, and J. Hu. 2017. Genome-wide gene expression profiling reveals that $C D 274$ is up-regulated new-onset type-1 diabetes mellitus. Acta Diabetol. 54:757-767. https://doi.org/10.1007/s00592 $-017-1005-y$.

Freebern, E., D. J. A. Santos, L. Fang, J. Jiang, K. L. Parker Gaddis, G. E. Liu, P. M. VanRaden, C. Maltecca, J. B. Cole, and L. Ma. 2020. GWAS and fine-mapping of livability and six disease traits in Holstein cattle. BMC Genomics 21:41. https://doi.org/10.1186/ s12864-020-6461-z.

Fukao, T., G. D. Lopaschuk, and G. A. Mitchell. 2004. Pathways and control of ketone body metabolism: On the fringe of lipid biochemistry. Prostaglandins Leukot. Essent. Fatty Acids 70:243-251. https://doi.org/10.1016/j.plefa.2003.11.001.

Gernand, E., R. Waßmuth, U. U. von Borstel, and S. König. 2007. Heterogeneity of variance components for production traits in large-scale dairy farms. Livest. Sci. 112:78-89. https://doi.org/10 $.1016 / j$.livsci.2007.01.157.

Geyer, P. E., N. J. Wewer Albrechtsen, S. Tyanova, N. Grassl, E. W. Iepsen, J. Lundgren, S. Madsbad, J. J. Holst, S. S. Torekov, and M. Mann. 2016. Proteomics reveals the effects of sustained weight loss on the human plasma proteome. Mol. Syst. Biol. 12:901. https: //doi.org/10.15252/msb.20167357.

Goddard, M. E., K. E. Kemper, I. M. MacLeod, A. J. Chamberlain, and B. J. Hayes. 2016. Genetics of complex traits: Prediction of phenotype, identification of causal polymorphisms and genetic ar- chitecture. Proc. Biol. Sci. 283:20160569. https://doi.org/10.1098/ rspb.2016.0569.

Grelet, C., C. Bastin, M. Gelé, J.-B. Davière, M. Johan, A. Werner, R. Reding, J. A. Fernandez Pierna, F. G. Colinet, P. Dardenne, N. Gengler, H. Soyeurt, and F. Dehareng. 2016. Development of Fourier transform mid-infrared calibrations to predict acetone, $\beta$-hydroxybutyrate, and citrate contents in bovine milk through a European dairy network. J. Dairy Sci. 99:4816-4825. https://doi .org/10.3168/jds.2015-10477.

Häggman, J., J. M. Christensen, E. A. Mäntysaari, and J. Juga. 2019 Genetic parameters for endocrine and traditional fertility traits, hyperketonemia and milk yield in dairy cattle. Animal 13:248-255. https://doi.org/10.1017/S1751731118001386.

Hasstedt, S. J., H. M. Highland, S. C. Elbein, C. L. Hanis, and S. K. Das. 2013. Five linkage regions each harbor multiple type 2 diabetes genes in the African American subset of the GENNID Study. J. Hum. Genet. 58:378-383. https://doi.org/10.1038/jhg.2013.21.

Hayirli, A. 2006. The role of exogenous insulin in the complex of hepatic lipidosis and ketosis associated with insulin resistance phenomenon in postpartum dairy cattle. Vet. Res. Commun. 30:749774. https://doi.org/10.1007/s11259-006-3320-6.

Heringstad, B., Y. M. Chang, D. Gianola, and G. Klemetsdal. 2005. Genetic analysis of clinical mastitis, milk fever, ketosis, and retained placenta in three lactations of Norwegian red cows. J. Dairy Sci. 88:3273-3281. https://doi.org/10.3168/jds.S0022 -0302(05)73010-1.

Hillreiner, M., C. Flinspach, M. W. Pfaffl, and H. Kliem. 2016. Effect of the ketone body beta-hydroxybutyrate on the innate defense capability of primary bovine mammary epithelial cells. PLoS One 11:e0157774. https://doi.org/10.1371/journal.pone.0157774.

Huang, H., J. Cao, Q. Hanif, Y. Wang, Y. Yu, S. Zhang, and Y. Zhang. 2019. Genome-wide association study identifies energy metabolism genes for resistance to ketosis in Chinese Holstein cattle. Anim. Genet. 50:376-380. https://doi.org/10.1111/age.12802.

Jang, C., S. F. Oh, S. Wada, G. C. Rowe, L. Liu, M. C. Chan, J. Rhee, A. Hoshino, B. Kim, A. Ibrahim, L. G. Baca, E. Kim, C. C. Ghosh, S. M. Parikh, A. Jiang, Q. Chu, D. E. Forman, S. H. Lecker, S. Krishnaiah, J. D. Rabinowitz, A. M. Weljie, J. A. Baur, D. L. Kasper, and Z. Arany. 2016. A branched-chain amino acid metabolite drives vascular fatty acid transport and causes insulin resistance. Nat. Med. 22:421-426. https://doi.org/10.1038/nm.4057.

Karnes, J. H., C. W. McDonough, Y. Gong, T. T. Vo, T. Y. Langaee, A. B. Chapman, J. G. Gums, A. L. Beitelshees, K. R. Bailey, J. L. Del-Aguila, E. A. Boerwinkle, C. J. Pepine, S. T. Turner, J. A. Johnson, and R. M. Cooper-DeHoff. 2013. Association of KCNJ1 variation with change in fasting glucose and new onset diabetes during HCTZ treatment. Pharmacogenomics J. 13:430-436. https: //doi.org/10.1038/tpj.2012.34.

Klein, S.-L., C. Scheper, K. Brügemann, H. H. Swalve, and S. König. 2019. Phenotypic relationships, genetic parameters, genome-wide associations, and identification of potential candidate genes for ketosis and fat-to-protein ratio in German Holstein cows. J. Dairy Sci. 102:6276-6287. https://doi.org/10.3168/jds.2019-16237.

Koeck, A., J. Jamrozik, G. J. Kistemaker, F. S. Schenkel, R. K. Moore, D. M. Lefebvre, D. F. Kelton, and F. Miglior. 2016. Genetic and phenotypic associations of milk $\beta$-hydroxybutyrate with ketosis in Canadian Holsteins. Can. J. Anim. Sci. 96:302-305. https://doi .org/10.1139/cjas-2015-0206.

Koeck, A., F. Miglior, J. Jamrozik, D. F. Kelton, and F. S. Schenkel. 2013. Genetic associations of ketosis and displaced abomasum with milk production traits in early first lactation of Canadian Holsteins. J. Dairy Sci. 96:4688-4696. https://doi.org/10.3168/jds .2012-6408.

König, S., and K. May. 2019. Invited review: Phenotyping strategies and quantitative-genetic background of resistance, tolerance and resilience associated traits in dairy cattle. Animal 13:897-908. https://doi.org/10.1017/S1751731118003208.

Koenig, S., R. Sharifi, H. Wentrot, D. Landmann, M. Eise, and H. Simianer. 2005. Genetic parameters of claw and foot disorders es- 
timated with logistic models. J. Dairy Sci. 88:3316-3325. https:// doi.org/10.3168/jds.S0022-0302(05)73015-0.

Kroezen, V., F. S. Schenkel, F. Miglior, C. F. Baes, and E. J. Squires. 2018. Candidate gene association analyses for ketosis resistance in Holsteins. J. Dairy Sci. 101:5240-5249. https://doi.org/10.3168/ jds.2017-13374.

Kurz, J. P., Z. Yang, R. B. Weiss, D. J. Wilson, K. A. Rood, G. E. Liu, and Z. Wang. 2019. A genome-wide association study for mastitis resistance in phenotypically well-characterized Holstein dairy cattle using a selective genotyping approach. Immunogenetics 71:35-47. https://doi.org/10.1007/s00251-018-1088-9.

Lee, S., K. Cho, M. Park, T. Choi, S. Kim, and C. Do. 2016. Genetic parameters of milk $\beta$-hydroxybutyric acid and acetone and their genetic association with milk production traits of Holstein cattle. Asian-Australas. J. Anim. Sci. 29:1530-1540. https://doi.org/10 $.5713 /$ ajas.16.0310.

Li, M.-X., J. M. Y. Yeung, S. S. Cherny, and P. C. Sham. 2012. Evaluating the effective numbers of independent tests and significant $p$-value thresholds in commercial genotyping arrays and public imputation reference datasets. Hum. Genet. 131:747-756. https://doi .org/10.1007/s00439-011-1118-2.

Lucy, M. C. 2004. Mechanisms linking the somatotropic axis with insulin: Lessons from the postpartum dairy cow. Proc. N.Z. Soc. Anim. Prod. 64:19-23.

Mach, N., Y. Blum, A. Bannink, D. Causeur, M. Houee-Bigot, S. Lagarrigue, and M. A. Smits. 2012. Pleiotropic effects of polymorphism of the gene diacylglycerol-O-transferase 1 (DGAT1) in the mammary gland tissue of dairy cows. J. Dairy Sci. 95:4989-5000. https://doi.org/10.3168/jds.2012-5348.

Madsen, P., and J. Jensen. 2013. DMU: A Package for Analysing Multivariate Mixed Models. Accessed Mar 22, 2017. http://dmu.agrsci .dk/DMU/Doc/Current/dmuv6_guide.5.2.pdf.

McCarthy, M. I., G. R. Abecasis, L. R. Cardon, D. B. Goldstein, J. Little, J. P. A. Ioannidis, and J. N. Hirschhorn. 2008. Genomewide association studies for complex traits: Consensus, uncertainty and challenges. Nat. Rev. Genet. 9:356-369. https://doi.org/10 $.1038 / \mathrm{nrg} 2344$.

McCarthy, S. D., S. M. Waters, D. A. Kenny, M. G. Diskin, R. Fitzpatrick, J. Patton, D. C. Wathes, and D. G. Morris. 2010. Negative energy balance and hepatic gene expression patterns in high-yielding dairy cows during the early postpartum period: A global approach. Physiol. Genomics 42A:188-199. https://doi.org/10.1152/ physiolgenomics.00118.2010.

Mehtiö, T., P. Mäntysaari, E. Negussie, A.-M. Leino, J. Pösö, E. A. Mäntysaari, and M. H. Lidauer. 2020. Genetic correlations between energy status indicator traits and female fertility in primiparous Nordic Red Dairy cattle. Animal 14:1588-1597. https://doi .org/10.1017/S1751731120000439.

Mostert, P. F., E. A. M. Bokkers, C. E. van Middelaar, H. Hogeveen, and I. J. M. de Boer. 2018. Estimating the economic impact of subclinical ketosis in dairy cattle using a dynamic stochastic simulation model. Animal 12:145-154. https://doi.org/10.1017/ S1751731117001306.

Nahon, J. E., M. Hoekstra, V. van Harmelen, P. C. N. Rensen, K. Willems van Dijk, S. Kooijman, and M. Van Eck. 2019. Proteoglycan 4 deficiency protects against glucose intolerance and fatty liver disease in diet-induced obese mice. Biochim. Biophys. Acta Mol. Basis Dis. 1865:494-501. https://doi.org/10.1016/j.bbadis.2018.11 .009 .

Nayeri, S., F. Schenkel, A. Fleming, V. Kroezen, M. Sargolzaei, C. Baes, A. Cánovas, J. Squires, and F. Miglior. 2019. Genome-wide association analysis for $\beta$-hydroxybutyrate concentration in milk in Holstein dairy cattle. BMC Genet. 20:58. https://doi.org/10.1186/ s12863-019-0761-9.

Osorio, J. S., J. Lohakare, and M. Bionaz. 2016. Biosynthesis of milk fat, protein, and lactose: Roles of transcriptional and posttranscriptional regulation. Physiol. Genomics 48:231-256. https://doi .org/10.1152/physiolgenomics.00016.2015.

Parker Gaddis, K. L., J. H. Megonigal Jr., J. S. Clay, and C. W. Wolfe. 2018. Genome-wide association study for ketosis in US Jerseys us- ing producer-recorded data. J. Dairy Sci. 101:413-424. https://doi .org/10.3168/jds.2017-13383.

Purcell, S., B. Neale, K. Todd-Brown, L. Thomas, M. A. R. Ferreira, D. Bender, J. Maller, P. Sklar, P. I. W. de Bakker, M. Daly, and P. C. Sham. 2007. PLINK: A tool set for whole-genome association and population-based linkage analyses. Am. J. Hum. Genet. 81:559-575. https://doi.org/10.1086/519795.

Ranaraja, U., K. Cho, M. Park, S. Kim, S. Lee, and C. Do. 2018. Genetic parameter estimation for milk $\beta$-hydroxybutyrate and acetone in early lactation and its association with fat to protein ratio and energy balance in Korean Holstein cattle. Asian-Australas. J. Anim. Sci. 31:798-803. https://doi.org/10.5713/ajas.17.0443.

Santschi, D. E., R. Lacroix, J. Durocher, M. Duplessis, R. K. Moore, and D. M. Lefebvre. 2016. Prevalence of elevated milk $\beta$-hydroxybutyrate concentrations in Holstein cows measured by Fourier-transform infrared analysis in Dairy Herd Improvement milk samples and association with milk yield and components. J. Dairy Sci. 99:9263-9270. https://doi.org/10.3168/jds.2016-11128.

Satoła, A., and E. Ptak. 2019. Genetic parameters of milk fat-toprotein ratio in first three lactations of Polish Holstein-Friesian cows. J. Anim. Feed Sci. 28:97-109. https://doi.org/10.22358/jafs/ $105624 / 2019$.

Segelke, D., J. Chen, Z. Liu, F. Reinhardt, G. Thaller, and R. Reents. 2012. Reliability of genomic prediction for German Holsteins using imputed genotypes from low-density chips. J. Dairy Sci. 95:54035411. https://doi.org/10.3168/jds.2012-5466.

Sejersen, H., M. T. Sørensen, T. Larsen, E. Bendixen, and K. L. Ingvartsen. 2012. Liver protein expression in dairy cows with high liver triglycerides in early lactation. J. Dairy Sci. 95:2409-2421. https://doi.org/10.3168/jds.2011-4604.

Stock, K. F., J. Cole, J. Pryce, N. Gengler, A. J. Bradley, L. Andrews, B. Heringstad, and C. Egger-Danner. 2013. Standardization of health data-ICAR guidelines including health key. ICAR Tech. Ser. 17:75-81.

Suthar, V. S., J. Canelas-Raposo, A. Deniz, and W. Heuwieser. 2013. Prevalence of subclinical ketosis and relationships with postpartum diseases in European dairy cows. J. Dairy Sci. 96:2925-2938. https://doi.org/10.3168/jds.2012-6035.

Tetens, J., T. Seidenspinner, N. Buttchereit, and G. Thaller. 2013. Whole-genome association study for energy balance and fat/protein ratio in German Holstein bull dams. Anim. Genet. 44:1-8. https://doi.org/10.1111/j.1365-2052.2012.02357.x.

van der Drift, S. G. A., R. Jorritsma, J. T. Schonewille, H. M. Knijn, and J. A. Stegeman. 2012. Routine detection of hyperketonemia in dairy cows using Fourier transform infrared spectroscopy analysis of $\beta$-hydroxybutyrate and acetone in milk in combination with test-day information. J. Dairy Sci. 95:4886-4898. https://doi.org/ $10.3168 /$ jds.2011-4417.

van Knegsel, A. T. M., S. G. A. van der Drift, M. Horneman, A. P. W. de Roos, B. Kemp, and E. A. M. Graat. 2010. Short communication: Ketone body concentration in milk determined by Fourier transform infrared spectroscopy: Value for the detection of hyperketonemia in dairy cows. J. Dairy Sci. 93:3065-3069. https://doi .org $/ 10.3168 /$ jds.2009-2847.

Vanholder, T., J. Papen, R. Bemers, G. Vertenten, and A. C. B. Berge. 2015. Risk factors for subclinical and clinical ketosis and association with production parameters in dairy cows in the Netherlands. J. Dairy Sci. 98:880-888. https://doi.org/10.3168/jds.2014-8362.

Vinson, W. E., J. M. White, and R. H. Kliewer. 1976. Overall classification as a selection criterion for improving categorically scored components of type in Holstein. J. Dairy Sci. 59:2104-2114. https: //doi.org/10.3168/jds.S0022-0302(76)84494-3.

Weigel, K. A., R. S. Pralle, H. Adams, K. Cho, C. Do, and H. M. White. 2017. Prediction of whole-genome risk for selection and management of hyperketonemia in Holstein dairy cattle. J. Anim. Breed. Genet. 134:275-285. https://doi.org/10.1111/jbg.12259.

Wiklund, P., X. Zhang, S. Pekkala, R. Autio, L. Kong, Y. Yang, S. Keinänen-Kiukaanniemi, M. Alen, and S. Cheng. 2016. Insulin resistance is associated with altered amino acid metabolism and 
adipose tissue dysfunction in normoglycemic women. Sci. Rep. 6:24540. https://doi.org/10.1038/srep24540.

Yang, J., S. H. Lee, M. E. Goddard, and P. M. Visscher. 2011. GCTA: A tool for genome-wide complex trait analysis. Am. J. Hum. Genet. 88:76-82. https://doi.org/10.1016/j.ajhg.2010.11.011.

Yang, J., N. A. Zaitlen, M. E. Goddard, P. M. Visscher, and A. L. Price. 2014. Advantages and pitfalls in the application of mixedmodel association methods. Nat. Genet. 46:100-106. https://doi .org/10.1038/ng.2876.

Zerbino, D. R., P. Achuthan, W. Akanni, M. R. Amode, D. Barrell, J. Bhai, K. Billis, C. Cummins, A. Gall, C. G. Girón, L. Gil, L. Gordon, L. Haggerty, E. Haskell, T. Hourlier, O. G. Izuogu, S. H. Janacek, T. Juettemann, J. K. To, M. R. Laird, I. Lavidas, Z. Liu, J. E. Loveland, T. Maurel, W. McLaren, B. Moore, J. Mudge, D. N. Murphy, V. Newman, M. Nuhn, D. Ogeh, C. K. Ong, A. Parker, M. Patricio, H. S. Riat, H. Schuilenburg, D. Sheppard, H. Sparrow, K. Taylor, A. Thormann, A. Vullo, B. Walts, A. Zadissa, A. Frankish, S. E. Hunt, M. Kostadima, N. Langridge, F. J. Martin, M. Muffato, E. Perry, M. Ruffier, D. M. Staines, S. J. Trevanion, B. L. Aken, F. Cunningham, A. Yates, and P. Flicek. 2018. Ensembl
2018. Nucleic Acids Res. 46(D1):D754-D761. https://doi.org/10 .1093/nar/gkx1098.

Zhang, Q., K.-H. Wu, J.-Y. He, Y. Zeng, J. Greenbaum, X. Xia, H.-M. Liu, W.-Q. Lv, X. Lin, W.-D. Zhang, Y.-L. Xi, X.-Z. Shi, C.-Q. Sun, and H.-W. Deng. 2017. Novel common variants associated with obesity and type 2 diabetes detected using a cFDR method. Sci. Rep. 7:16397. https://doi.org/10.1038/s41598-017-16722-6.

Zhou, C., C. Li, W. Cai, S. Liu, H. Yin, S. Shi, Q. Zhang, and S. Zhang. 2019. Genome-wide association study for milk protein composition traits in a Chinese Holstein Population using a single-step approach. Front. Genet. 10:72. https://doi.org/10.3389/fgene.2019 .00072 .

\section{ORCIDS}

S.-L. Klein @ $\odot$ https://orcid.org/0000-0003-0976-4237

C. Scheper ๑ https://orcid.org/0000-0003-1189-2297

S. König @ https://orcid.org/0000-0002-1716-2511 